\title{
DISTRIBUTION, SURVIVORSHIP AND MORTALITY SOURCES IN IMMATURE STAGES OF THE NEOTROPICAL LEAF MINER Pachyschelus coeruleipennis KERREMANS (COLEOPTERA: BUPRESTIDAE)
}

\author{
QUEIROZ, J. M. \\ Departamento de Zoologia, Universidade Estadual de Campinas, C.P. 6109, CEP 13083-970, \\ Campinas, SP, Brazil \\ Correspondence to: Jarbas Marçal Queiroz, Museu de Zoologia da Universidade de São Paulo, Av. Nazaré, 481, \\ CEP 04263-000, São Paulo, SP, Brazil, e-mail: jqueiroz2001@yahoo.com.br \\ Received September 14, 2000 - Accepted December 1, 2000 - Distributed February 28, 2002
}

(With 3 figures)

\begin{abstract}
Distribution, sources of mortality, and survivorship of immatures was investigated during the reproductive season of the neotropical buprestid leaf miner, Pachyschelus coeruleipennis, that burrows in leaves of Croton floribundus (Euphorbiaceae) in SE, Brazil. Immature distribution was investigated by a random sample of 120 shrubs of $C$. floribundus growing along forest edges. Marked leaves were followed to recorded sources of mortality and survivorship of immature stages. Females lay their eggs preferentially in the young leaves of the host plant, with mines and pupal cells having been found on the middle part of plants. Densities of eggs, active mines, and pupal cells were, respectively, $25 \pm 2$, $6 \pm 1$, and $1 \pm 0.3$ per 100 leaves. Predators and parasitoids accounted for the majority of losses in the immature $P$. coeruleipennis population. Mortality was 3 times lower in the egg stage than in the last larval instar. Predation rate was greater than parasitism but the latter increased much more during the development of immatures. Survivorship and sources of mortality were different between early and late season sample of leaf-miner immatures. Parasitism rate was greater in the late-season whereas predation was greater in early-season samples. These results are compared with mortality patterns described for other buprestid leaf miners in temperate and tropical regions.
\end{abstract}

Key words: natural enemies, parasitism, predation, insect life history, Croton floribundus, Buprestidae leafminer, Pachyschelus coeruleipennis.

\section{RESUMO}

Distribuição, sobrevivência e fontes de mortalidade para estágios imaturos do minador de folhas neotropical Pachyschelus coeruleipennis Kerremans (Coleoptera: Buprestidae)

A distribuição, as fontes de mortalidade e a sobrevivência de estágios imaturos do minador de folhas Pachyschelus coeruleipennis (Coleoptera: Buprestidae) foram investigadas em uma floresta semidecídua do Sudeste brasileiro. A distribuição dos imaturos foi avaliada em uma amostra aleatória de 120 plantas jovens de Croton floribundus (Euphorbiaceae) às margens da floresta. Folhas com estágios imaturos do minador foram marcadas e observadas periodicamente para o registro da sobrevivência e das causas de morte. Fêmeas de $P$. coeruleipennis ovipositam preferencialmente em folhas da porção superior de plantas jovens, sendo que as minas com larvas e as células pupais são encontradas nas folhas da porção média. As densidades de ovos, as minas ativas e as células pupais foram, respectivamente, de $25 \pm 2,6 \pm 1$ and $1 \pm 0,3$ por 100 folhas. Predadores e parasitóides foram responsáveis pela maior porcentagem entre os fatores identificados de causas mortis. A taxa de predação foi superior à de 
parasitoidismo, mas esta última apresentou aumento mais acentuado durante o desenvolvimento dos imaturos. O padrão de sobrevivência e a composição nas causas mortis foram diferentes entre a amostra para o começo e para o final da estação reprodutiva. O parasitoidismo foi maior no final da estação, enquanto a predação o foi no início da estação. Os resultados deste trabalho são comparados com os padrões descritos para outros buprestídeos minadores de folha em regiões temperadas e tropicais.

Palavras-chave: minadores de folhas, inimigos naturais, parasitoidismo, predação, Croton floribundus, Pachyschelus coeruleipennis.

\section{INTRODUCTION}

Leafminers can be easily studied because they leave conspicuous records of their presence on leaves. Although the importance of their effect on natural communities may be questioned (Hespenheide, 1991), their particular feeding habits has inspired comparative studies on survivorship of herbivore insects (e.g., Cornell, 1990). In recent years, many researchers have studied survivorship and mortality of herbivore insects, but due to the paucity of data from tropical and subtropical latitudes, former patterns need further support from field studies (see Cornell \& Hawkins, 1995).

As a result of comparing life history styles among herbivorous insects, Cornell (1990) showed that leafminer survivorship ranges from convex to slightly concave, with age-specific mortality tending to increase with age. Many leaf-miner species support rich parasitoid complexes and suffer greater parasitoid-induced mortality (Hawkins, 1994). Crawling predators, specially ants, have been reported as important sources of leaf-miner mortality and sometimes may surpass parasitism (Faeth, 1980; Memmott et al., 1993; Pezzolesi \& Hager, 1994). Furthermore, damage to leaves by external feeding herbivores may increase parasitoid efficiency and shift the importance of predation and parasitism to leaf-miner mortality (Faeth, 1985). On the other hand, intraspecific competition and early leaf abscission have been reported as causing great mortality for some leaf-miner species of temperate regions (Faeth et al., 1981; Potter, 1985; Faeth, 1990).

In fact, studies of tropical leaf miners are mainly concerned with species description or concentrated on economically important species. Studies from temperate regions, however, have concentrated on lepidopteran leaf miners (see Hespenheide, 1991). Among beetle leafminers, buprestids have been studied several times (e.g., Kogan, 1963, 1964; Hespenheide \& Kim, 1992; Story et al.,
1979; Turnbow Jr. \& Franklin, 1981; Connor, 1988). Pachyschelus species are neotropical in distribution and have been studied in Brazil by Kogan (1963; 1964) and in Central America by Hespenheide \& Kim (1992). However, survivorship and sources of mortality have been investigated only in Central American species. For this paper, I examined the distribution, sources of mortality, and survivorship of immature stages of another Pachyschelus species, P. coeruleipennis Kerremans, in Southeastern Brazil.

\section{METHODS}

\section{Biology}

Pachyschelus coeruleipennis (Coleoptera: Buprestidae) mine leaves of Croton floribundus (Euphorbiaceae) in Southeastern Brazil from December to June. Although there are three other Croton species in the study area, $P$. coeruleipennis only mines leaves of $C$. floribundus. The leafminer is particularly abundant in the first months of the year when adults can be seen feeding and copulating on the upper side of host plant leaves.

Females lay their eggs ( $1 \mathrm{~mm}$ in diameter $)$ singly on the underside of leaves, beside the midvein or in the junction of secondary ribs. Recent oviposition is greenish in appearance because the epidermal flap covers the egg, then becomes brownish. Egg chorions stay attached after larval eclosion. Mines are serpentine in shape and there are three larval stadia. Development of immatures on leaves takes $\approx 1$ month. Mines of first instar larvae average $41 \mathrm{~mm}$ in length and $\approx 1 \mathrm{~mm}$ in thickness. In the second and third stadia, mines average, respectively, $64 \mathrm{~mm}$ and $152 \mathrm{~mm}$ in length. The thickness reaches $3 \mathrm{~mm}$. Larvae of third instars usually cross the midvein and pupate in the leaf. Total mine length is about $258 \mathrm{~mm}$. The pupal case averages $10 \mathrm{~mm}$ in diameter and after a few days falls to the soil from which the adults emerge (see Fig. 1 for the leaf-miner immature stages). 


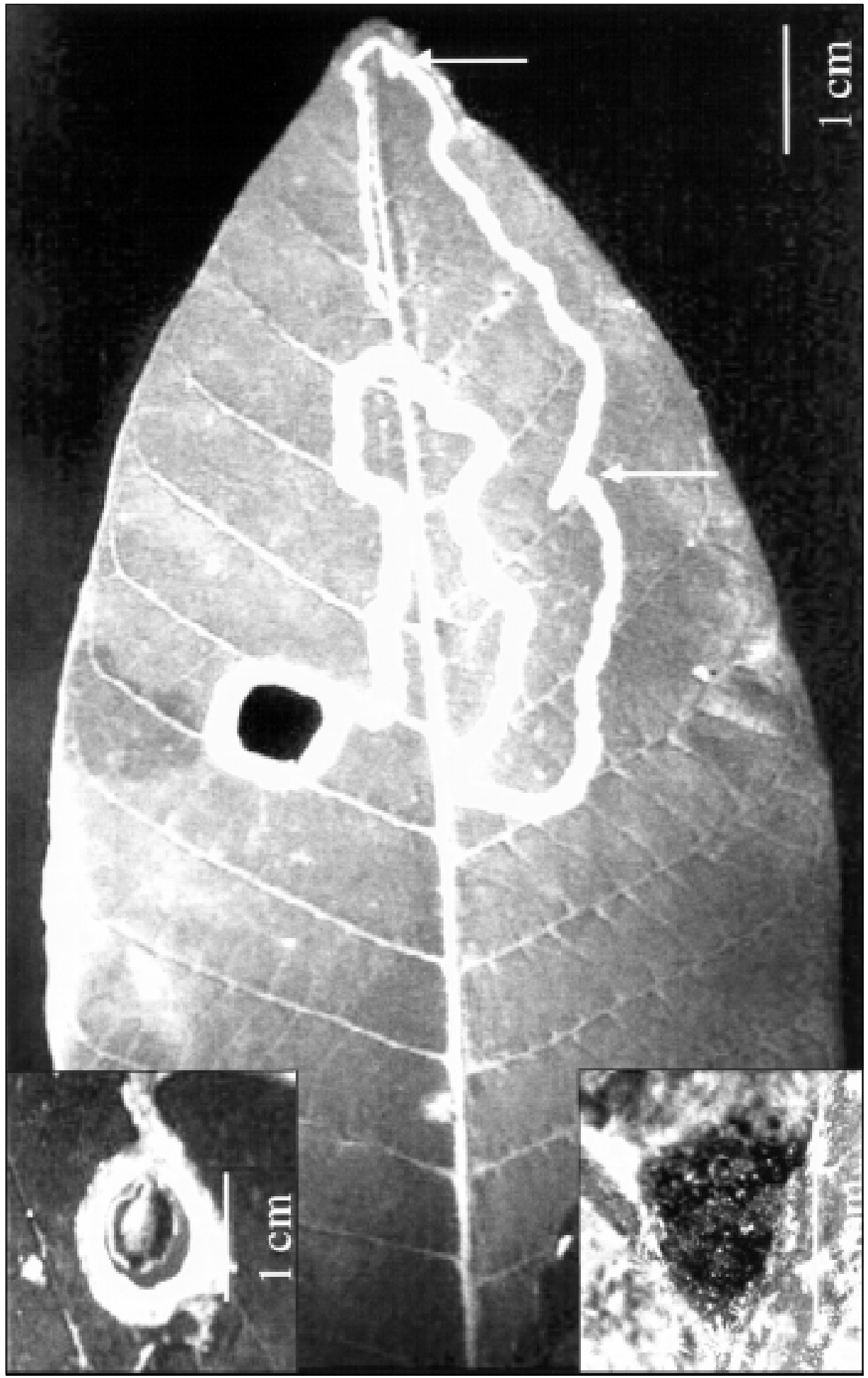

Fig. 1 - Picture of a mined leaf of Croton floribundus. Arrows are indicating the place of larval moults. In the botton left is the pupal case attached to the leaf. In the bottom right is the leaf-miner egg on the underside of leaf. 


\section{Procedures}

This study was conducted along trails at the border of a semideciduous forest in Serra do Japi Reserve (2316’S, 4700’W), Jundiaí, SP, Brazil. I determined the distribution pattern of the leafminer by examining leaves of 120 Croton shrubs (50$100 \mathrm{~cm}$ length and 5-20 leaves per plant) in February, 1999. Leaves were inspected for eggs and larvae of $P$. coeruleipennis. Position of leaves on plants and eggs on leaves were noted and each leaf with eggs or mines was labelled with tape and observed so as to count active mines (larva still feeding), dead mines, and pupal cells. During one month I observed weekly 100 plants to determine the position of leaves within plants with recently oviposited eggs. This procedure allowed me to analyse how the eggs were distributed in relation to leaf position on the plants. Thereafter, I observed plants biweekly to record causes of immature mortality in the field until June, when all individuals were either dead or pupated. When mortality causes could not be determined in the field, leaves were cut off, brought to the laboratory, and examined under a stereomicroscope.

Mortality due to parasitism was determined by the presence of circular openings on eggs and mines. It was attributed to larval predation when the mines were ripped open or had predation scars and larvae were missing. I also observed some larvae that were killed by fungi. Interspecific interactions occurred when eggs or mines had been eaten by a folivorous insect, in which case larvae had either disappeared or desiccated. Host-plant mortality factors include leaf abscission and larvae that died when crossing the midvein. Mortality was attributed to intraspecific competition when mines had met on a leaf and larvae were dead.

I examined 285 eggs distributed on 198 leaves. Eggs that failed to hatch, dead larvae, and pupal cells found on the first inspection in February/1999 were considered as the EARLY SEASON sample $(\mathrm{N}=120)$. Eggs recently oviposited (greenish appearance) and eggs oviposited after the first inspection composed the LATE SEASON sample $(\mathrm{N}=165)$.

\section{RESULTS}

In February, when I first inspected 120 plants, I found $313 \mathrm{eggs}$ on 1,265 leaves $(25 \pm 2 \mathrm{eggs} /$
100 leaves). Of those eggs, 73 had hatched and the larvae were still feeding ( 6 active mines \pm 1 / 100 leaves); 70 mines had dead larvae; and I found 13 pupal cells ( $1 \pm 0.3 / 100$ leaves $)$. The maximum number of eggs per leaf was 6 , but most leaves had only one egg (71\% of all leaves with eggs).

Most of the eggs from recent ovipositions were found on the top leaves of $C$. floribundus. There was a significant preference by females for ovipositing in the upper portion of plants $\left(\chi^{2}=41.45\right.$, d.f. $=4$, $\mathrm{p}<0.001)$. If eggs are put there, then active mines and pupal cells are found in the middle part due to the flow of new leaves (Fig. 2).

Natural enemies were the most important factor contributing to mortality among immature stages. Predation, parasitism, and fungal attack accounted for $37.1 \%$ of all ends, and predation rate was greater than that for parasitism (see Table 1). Parasitoid fauna from leaf-miner immatures were all hymenopterans, composed of 1 species of Braconidae and 6 species of Chalcidoidea. The mortality due to interaction with external feeding herbivores, mainly larvae of Anaea spp. (Lepidoptera: Charaxinae), accounted for $9.8 \%$. The occurrence of foliar abscission before leaf miners had been completely developed was recorded only 8 times and it was greater for the last larval instar. Intraspecific competition was relatively unimportant as a mortality source for Pachyschelus immatures, accounting for only $1.7 \%$ of the cases. Survival of immatures was 3 times greater for the eggs than for the last larval instar $(75 \% \mathrm{Vs}$. $25 \%$ ). A great amount of third instar larvae died from parasitism, the rate of which increased much more than did predation among larval instar (see Table 1).

There were differences in the mortality patterns between early and late season samples. The death rate increased for all sources except predation in the late-season sample (Table 1). Therefore, mortality of leaf-miner immatures was lower in the early-season than in the late-season sample, when it increased $16.5 \%$. The contribution of predation to leaf-miner mortality was far more important in early- than in the late-season sample (29.2\% Vs. 12.7\%). In spite of the great increases in the parasitism rate in the late-season sample, the effects of predation and parasitism on leafminer mortality in the late-season population was almost the same (see Table 1). 
IMMATURE DISTRIBUTION OF Pachyschelus coeruleipennis WITHIN PLANT

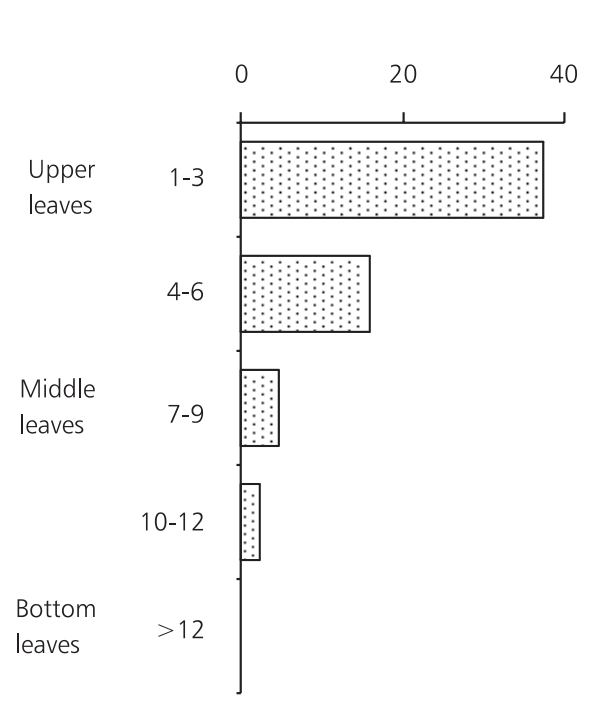

Eggs (a)
Density per 100 leaves

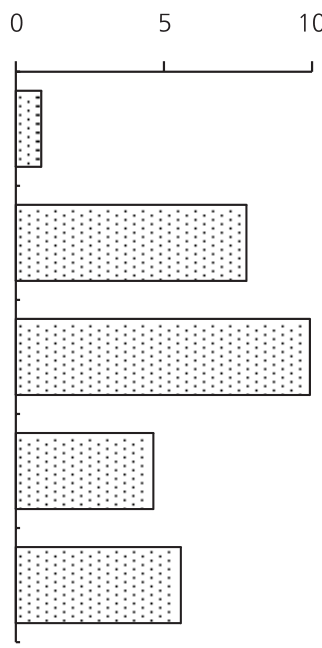

Active mines (b)

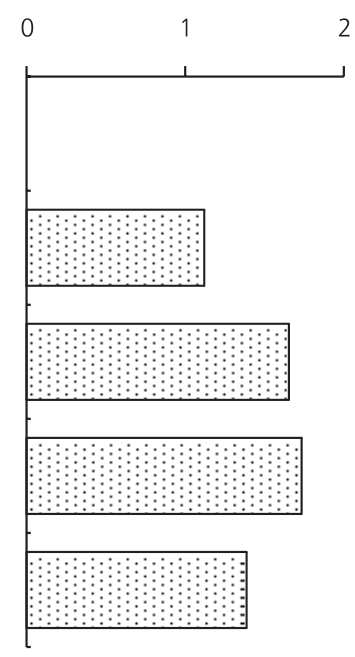

Pupae cells (c)

Fig. 2 - Densities of immature leafminers within five classes of leaf position (three leaves per category) recorded in FebruaryMarch/1999 on shrubs of $C$. floribundus in SE, Brazil. (a) only eggs oviposited during 1 month (observed at 5-days interval) are represented, (b) mines with larvae still feeding, and (c) pupal cells, see that they were not found in the top class of leaf position.

TABLE 1

Proportion and sources of mortality among immature lifestages of Pachyschelus coeruleipennis.

\begin{tabular}{|l|c|c|c|c|c|c|c|c|}
\hline Stages & Predation & Parasitism & Fungi & Eaten** & Plant & Comp.*** & Unknown & Total \\
\hline Eggs & 0.7 & 1.4 & 0 & 2.8 & 1.4 & 0 & 18.2 & 24.5 \\
L1* & 5.6 & 2.8 & 2.8 & 4.6 & 1.9 & 0.9 & 13 & 31.6 \\
L2 & 14.3 & 1.3 & 0.7 & 5.4 & 5.4 & 0.7 & 9.5 & 37.4 \\
L3 & 22.8 & 33.7 & 0 & 2.2 & 3.3 & 2.2 & 10.8 & 75 \\
\hline $\begin{array}{l}\text { Early } \\
\text { season } \\
\text { Late } \\
\text { season }\end{array}$ & 29.2 & 10.8 & 0.8 & 10 & 5.8 & 0 & 27.5 & 84.1 \\
\hline Total & 12.7 & 18.2 & 4.2 & 9.7 & 7.3 & 3 & 43 & 98 \\
\hline
\end{tabular}

* First instar larvae.

** Mortality resulting from interaction with external feeding herbivores.

*** Mortality due to intraspecific competition. 
The survivorship curves for the two samples were different and maximum divergence occurred in the last larval instar (Fig. 3).

\section{DISCUSSION}

Distribution of Pachyschelus coeruleipennis immature stages within plants was vertically stratified because females oviposited preferentially on the upper Croton leaves. The mechanisms of this choice is unknown, however I suggest that this selective oviposition behaviour could prevent leaf miners from sharing leaves due to the flow of new leaves. Although $70 \%$ of attacked leaves had only one egg of $P$. coeruleipennis, the mean density of immatures in the sample was not very low (20$40 \%$ of mined leaves), if compared with leaf-miner species from North America (e.g., Faeth, 1990). Similar low densities of immatures per leaf were observed for other Pachyschelus species in Brazil (Kogan, 1963, 1964). As a consequence, intraspecific competition was unimportant as a mortality cause in immature $P$. coeruleipennis. This is not true for several leaf miners in temperate regions, where clumping behavior among leaves of some species caused intraspecific competition and premature leaf abscission and, therefore, increased the mortality rates (Potter, 1985; Simberloff \& Stiling, 1987; Stiling et al., 1987; Faeth, 1990). Here, I observed that $P$. coeruleipennis exited leaves well before normal leaf fall and it seemed that mined leaves did not fall prior to normal leaf abscission. So, in addition, the observed low mortality rate of leaf-miners due to leaf abscission may be connected with upper leaves selection by leafminer females (see Bultman \& Faeth, 1986).

Previous studies have suggested that parasitoids represent a more potent source of mortality in herbivore insects in the temperate zone than in the tropics, whereas predation pressures are greater in the tropics (e.g., Hawkins et al., 1997). As for many other herbivorous insect species (see Cornell \& Hawkins, 1995), parasitism and predation were also the main mortality factors identified in the population of $P$. coeruleipennis in SE, Brazil. I was unable to identify the majority of mortality factors occurring in the egg stage. I think, however, that most unhatched eggs could have been attacked by a sucking predator, but, to be conservative, I attributed these losses to unknown factors.

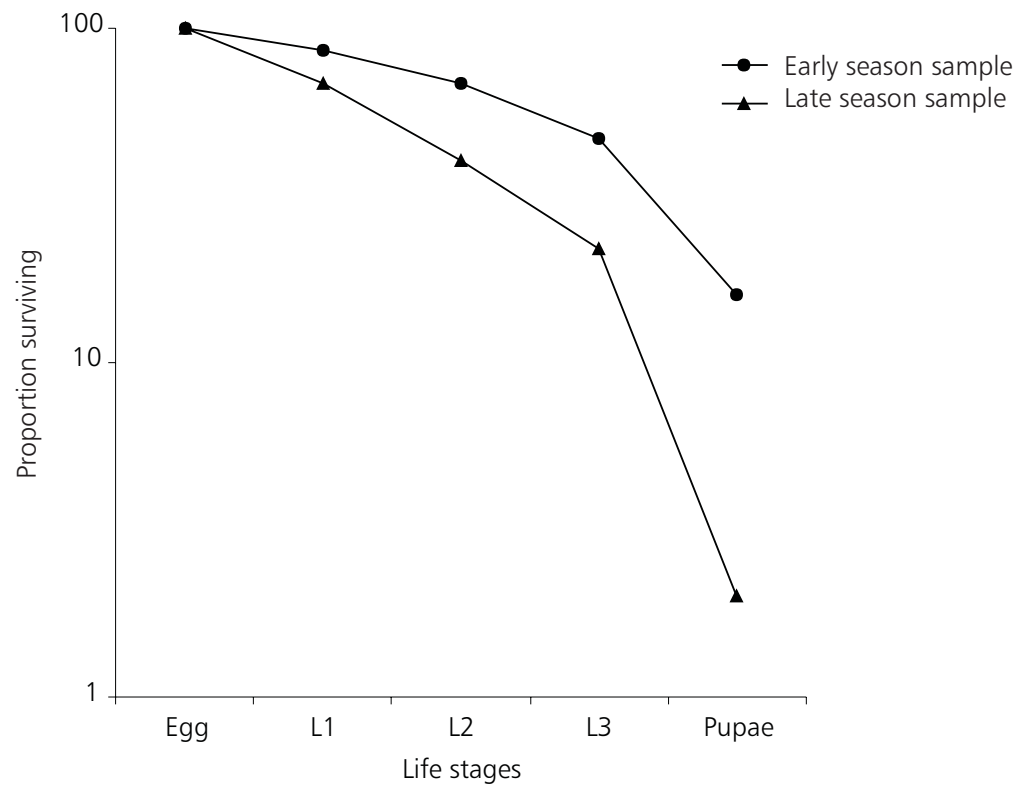

Fig. 3 - Survivorship of immature $P$. coeruleipennis on leaves of $C$. floribundus for two seasons. Data are represented in a log-scale. Note the great increase in last instar larvae mortality. 
An important result of this study was showing that the predation rate contributed more to $P$. coeruleipennis immature mortality than parasitism. Conversely, in Central America, parasitism was the main factor causing mortality in $P$. psychotriae immatures (Hespenheide \& Kim, 1992). Another buprestid genus of leaf miners that was studied in North America presented results too conflicting to reveal a pattern. Brachys tesselatus suffered great mortality from predation in the egg stage but there was no information about the contribution of each enemy to larvae mortality (Turnbow Jr. \& Franklin, 1981). On the other hand, B. ovatus suffered losses mainly from leaf abscission, and deaths from parasitoids were more common than from predators (Connor, 1988).

Although I recorded a high predation rate for immature $P$. coeruleipennis, I have not seen any predation event in the field. However, ants are frequently observed foraging on leaves of $C$. floribundus and perhaps they remove leaf-miner larvae. In fact, the importance of ants in regulating leaf-miner populations have been demonstrated previously, but observations of ants preying leafminer larvae have been rare (Faeth, 1980; Memmott et al., 1993; Pezzolesi \& Hager, 1994). If ants are important enemies of immatures $P$. coeruleipennis, I suggest that the variations of their foraging patterns on plants among seasons may be used to explain the different contributions of predators and parasitoids to mortality levels throughout leafminer occurrence.

The increased rate of immature mortality among successive stages of $P$. coeruleipennis, represented by a convex survivorship curve, may be explained by the presence of koinobiont parasitoids that attack egg and early larval stages but do not kill the host until late-larval and pupal stages (Cornell, 1990). P. psychotriae also suffered increased mortality during immature development (Hespenheide \& Kim, 1992), but another buprestid, B. ovatus, was more susceptible to death in the egg stage (Connor, 1988). Therefore, Pachyschelus has a more convex survivorship curve whereas Brachys presented a more concave curve, with higher mortality for the egg stage.

The population dynamic of $P$. coeruleipennis is highly seasonal with immatures occurring on leaves of $C$. floribundus from December through June. Leaf-miner females begin to oviposit in early summer (December) when there is a low number of external feeding larvae on Croton leaves and climatic conditions are better for rapid development of immature stages (mean temperature of $21.4^{\circ} \mathrm{C}$; monthly rainfall averages $280 \mathrm{~mm}$ ). Conversely, in the late season, damage to Croton leaves by external feeding herbivore reaches high levels. The number of butterfly larvae, for example, is at its peak in April (Brown Jr., 1992). This is important because those larvae feeding on Croton leaves usually caused the death of leaf miners. It was hypothesized that the seasonal phenology of lepidopterous leaf miners on Quercus in Britain may be constrained by external feeding caterpillars (West, 1985). The author observed that the magnitude of mortality due to unknown causes was greater when damage to Quercus leaves was increased and it was attributed in part to plant antibiosis effects (induced responses). Here, an increase of $56 \%$ in the mortality rate of $P$. coeruleipennis due to unknown causes was also observed in the late season sample. If this factor is connected with the increase in damage to Croton leaves remains to be investigated. Moreover, leaf miners can suffer additional losses from enemy attack due to induction by the external feeding activity of herbivores on leaves (see Faeth, 1985; Agrawal, 1998). Furthermore, the temperature goes down in late season and development time of immature stages is probably higher. Thus, leaf miners could be exposed for a longer period to attacks by natural enemies. Future experimental studies may help to explain the mechanisms underlying the seasonal abundance pattern of immature $P$. coeruleipennis in the forests of southeastern Brazil.

Acknowledgments - I am grateful to Henry Hespenheide (UCLA, USA) for identifying Pachyschelus species and to Paulo S. Oliveira and Sérgio Seike for their comments on drafts of this manuscript. I also thank the Staff of Serra do Japi Reserve for permission to work in that area. This study was supported by the Brazilian Government through a CAPES doctoral fellowship granted to the author.

\section{REFERENCES}

AGRAWAL, A. A., 1998, Leaf damage and associated cues induce aggressive ant recruitment in a neotropical antplant. Ecology, 79: 2100-2112.

BROWN Jr., K. S., 1992, Borboletas da Serra do Japi: diversidade, habitats, recursos alimentares e variação temporal. In: L. P. C. Morellato (org.), História natural da Serra do Japi. Editora da Unicamp/FAPESP, Campinas, Brasil, pp. 142-186. 
BULTMAN, T. L. \& FAETH, S. H., 1986, Selective oviposition by a leaf miner in response to temporal variation in abscission. Oecologia, 69: 117-120.

CONNOR, E. F., 1988, Cohort and death assemblages estimates of survival rates and causes of mortality in Brachys ovatus (Weber) (Coleoptera: Buprestidae). The American Midl. Naturalist, 120: 150-155.

CORNELL, H. V., 1990, Survivorship, life history, and concealment: a comparison of leaf miners and gall formers. American Naturalist, 136: 581-597.

CORNELL, H. V. \& HAWKINS, B. A., 1995, Survival patterns and mortality sources of herbivorous insects: some demographic trends. American Naturalist, 145: 563-593.

FAETH, S. H., 1980, Invertebrate predation of leaf-miners at low densities. Ecological Entomology, 5: 111-114.

FAETH, S. H., 1985, Host leaf selection by leaf miners: interactions among three trophic levels. Ecology, 66: 870-875.

FAETH, S. H., 1990, Aggregation of a leafminer, Cameraria sp. Nov. (Davis): consequences and causes. Journal of Animal Ecology, 59: 569-586.

FAETH, S. H., CONNOR, E. F. \& SIMBERLOFF, D., 1981, Early leaf abscission: a neglected source of mortality for folivores. American Naturalist, 117: 409-415.

HAWKINS, B. A., 1994, Pattern \& Process in host-parasitoid interaction. Cambridge University Press, 190p.

HAWKINS, B. A., CORNELL, H. V. \& HOCHBERG, M. E., 1997, Predators, parasitoids, and pathogens as mortality agents in phytophagous insect populations. Ecology, 78: $2145-2152$.

HESPENHEIDE, H. A., 1991, Bionomics of leaf-mining insects. Annu. Rev. Entomol., 36: 535-560.

HESPENHEIDE, H. A. \& KIM, C. O., 1992, Clutch size, survivorship, and biology of larval Pachyschelus psychotriae Fisher (Coleoptera: Buprestidae). Ann. of Entomol. Soc. Am., 85: 48-52.
KOGAN, M., 1963, Contribuição ao conhecimento da sistemática e biologia de buprestídeos minadores do gênero Pachyschelus Solier, 1833 (Coleoptera: Buprestidae). Mem. Inst. Oswaldo Cruz, 61: 429-458.

KOGAN, M., 1964, Estudos taxionômicos e biológicos sobre buprestídeos minadores do gênero Pachyschelus Solier, 1833, com a descrição de uma espécie nova (Insecta, Coleoptera). Mem. Inst. Oswaldo Cruz, 62: 63-76.

MEMMOTT, J., GODFRAY, H. C. J. \& BOLTON, B., 1993 Predation and parasitism in a tropical herbivore community. Ecological Entomology, 18: 348-352.

PEZZOLESI, L. S. W. \& HAGER, B. J., 1994, Ant predation on two species of birch leaf-mining sawflies. The Am. Midl. Nat., 131: 156-168.

POTTER, D. A., 1985, Population regulation of the native holly leaf-miner, Phytomiza ilicicola Loew (Diptera: Agromyzidae), on American holly. Oecologia, 66: 499-505.

SIMBERLOFF, D. \& STILING, P., 1987, Larval dispersion and survivorship in a leaf-mining moth. Ecology, 68: 16471657.

STILING, P., SIMBERLOFF, D. \& ANDERSON, L. C., 1987 Non-random distribution patterns of leaf miners on oak tree. Oecologia, 73: 116-119.

STORY, R. N., ROBINSON, W. H., PIENKOWSKI, R. L. \& KOK, L. T., 1979, The biology and immature stages of Taphrocerus schaefferi, a leaf-miner of yellow nutsedge. Ann. Ent. Soc. Am., 72: 93-98.

TURNBOW Jr., R. H. \& FRANKLIN, R. T., 1981, Bionomics of Brachys tessellatus in coastal plain scrub oak communities. Ann. Ent. Soc. Am., 74: 351-358.

WEST, C., 1985, Factors underlying the late seasonal appearance of the lepidopterous leaf-mining guild on oak. Ecological Entomology, 10: 111-120. 